\title{
Effects of roads on the vertebrates diversity of the Indigenous Territory Paresi and its surrounding
}

\author{
T. R. Brum ${ }^{a}$, M. Santos-Filho ${ }^{*}$, G. R. Canale $^{b}$ and A. R. A. Ignácio ${ }^{a}$ \\ áLaboratório de Mastozoologia, Centro de Estudos de Liminologia Biodiversidade e Etnobiologia do Pantanal - CELBE, \\ Universidade do Estado de Mato Grosso - UNEMAT, Av. Santos Dumont, Cidade Universitária, \\ CEP 78200-000, Cáceres, MT, Brazil \\ búcleo de Estudos da Biodiversidade da Amazônia Mato-Grossense - NEBAM, Instituto de Ciências Naturais, \\ Humanas e Sociais - ICNHS, Universidade Federal de Mato Grosso - UFMT, Av. Alexandre Ferronato, 1200, \\ Campus Universitário de Sinop - CUS, CEP 78557-267, Sinop, MT, Brazil \\ *e-mail: msantosfilho@gmail.com
}

Received: June 6, 2016 - Accepted: August 29, 2016 - Distributed: February 28, 2018

(With 2 figures)

\begin{abstract}
Roadkill impact is still underestimated due to the lack of knowledge of its intensity and effect on animal populations. To assess differences between animal roadkills on roads in distinct landscapes, this study recorded meso- and megavertebrate roadkills along $50 \mathrm{~km}$ during a year in two highways in the transitional area of Amazonia/Cerrado in Tangará da Serra, Mato Grosso: MT-358 and MT-235, the latter crossing the Paresi Indigenous Land. We assessed roadkill rates and points with higher rates of roadkills, recording the most impacted species, seasonal effects, biomass loss, activity period of species, and traffic volume. We recorded 178 roadkills in $4,950 \mathrm{~km}$ travelled, a rate of $0.035 \mathrm{animal} / \mathrm{km}$-travelled. Mammals were the most impacted with 135 roadkills (75.8\%), followed by reptiles $(6.2 \%)$, amphibians $(5.6 \%)$ and birds (5.1\%). Among mammals 51.1\% were Carnivora, and the most impacted species was Cerdocyon thous $(\mathrm{n}=42)$. On highway MT-358 (human-modified landscape), we recorded 155 roadkilled mammals, and the most impacted were C. thous (23.9\%) and Euphractus sexcinctus (13.5\%). Whilst on highway MT-235 (Paresi Indigenous Land), we recorded 23 roadkilled mammals, and the most impacted were Myrmecophaga tridactyla (26.1\%) and C. thous (21.7\%). The low roadkill rate in the Paresi Indigenous Land might be related to the presence of fauna pathways along the highway and the availability of a forested landscape.
\end{abstract}

Keywords: road ecology, mammal, roadkill, tropical forest, savanna.

\section{Efeitos das rodovias MT 235 e 358 sob a diversidade de vertebrados no sudoeste de Mato Grosso}

\section{Resumo}

O impacto de atropelamentos por veículos sobre populações animais ainda é subestimado devido ao pouco conhecimento existente sobre sua intensidade e seus efeitos. Para avaliar diferenças entre atropelamentos de animais em rodovias inseridas em paisagens distintas, este trabalho registrou atropelamentos de meso e mega vertebrados em trechos de $50 \mathrm{~km}$ durante um ano em duas rodovias na região de transição Amazônia/Cerrado em Tangará da Serra, Mato Grosso: MT-358 e MT-235, sendo que a segunda cruza a Terra Indígena Paresi. Avaliamos as taxas de atropelamento e os locais de maior intensidade, registrando as espécies mais impactadas. Avaliamos efeitos de sazonalidade, perda de biomassa, horário de atividade das espécies e horário de maior fluxo de veículos. Foram 178 animais atropelados em $4.950 \mathrm{~km}$ percorridos, com 33 espécies (15 ordens), totalizando 0,035 animais/km-percorrido. Os mamíferos foram os mais atingidos com 135 atropelamentos $(75,8 \%)$, seguidos por répteis $(6,2 \%)$, anfíbios $(5,6 \%)$ e aves $(5,1 \%)$. Entre os mamíferos atropelados $51,1 \%$ pertencem à ordem carnívora, e a espécie mais atropelada foi Cerdocyon thous $(\mathrm{n}=42)$. Na rodovia MT-358 (antropizada) foram registrados 155 atropelamentos de mamíferos, sendo que C. thous (23,9\%) e Euphractus sexcinctus $(13,5 \%)$ foram os mais atropelados. Enquanto na rodovia MT-235 foram registrados 23 atropelamentos sendo Myrmecophaga tridactyla (26.1\%) e C. thous $(21,7 \%)$ as espécies mais afetadas. Observamos menor taxa de atropelamentos dentro da Terra Indígena Paresi, possivelmente devido a presença de passagens para fauna ao longo da rodovia e maior quantidade de áreas florestadas.

Palavras-chave: ecologia de estrada, mamíferos, atropelamentos, floresta tropical, cerrado. 


\section{Introduction}

Around the world, the building and expansion of roads allows easy access between different areas and the transport of products, which are fundamental for the socioeconomic development of a region (Rosa et al., 2009). However, the adjacent ecosystems suffer a great impact with the building of roads, which are usually not planned adequately (Moreira et al., 2006).

Despite the fact that they facilitate regional development, ecologically speaking roads can function as barriers, subdividing habitats and animal populations (Brandt et al., 2001; Forman and Deblinger, 2000; Forman and Alexandre, 1998), causing the loss of biodiversity (Bager, 2006; Cheren et al., 2007), and allowing the introduction of exotic species (Forman et al., 2002). Besides the direct impact of roadkill, roads also generate demographic and genetic consequences for the local fauna when they prevent the free passage of the animals (Brandt et al., 2001; Forman and Alexandre, 1998).

Roadkill can negatively influence natural animal populations, especially when it eliminates young animals of reproductive age. This affects carnivores especially, since they have low population density, live in wide areas, and have low reproductive rates (Melo and Santos-Filho, 2007; Souza and Anacleto, 2012; Cáceres et al., 2012).

According to Castro (2007), in Brazil the building of roads is related to severe deforestation of native vegetation like the Amazon forest. It is necessary to adjust construction so that they allow animals to pass freely, not benefitting humans exclusively (Bissonette, 2002).

It is worth mentioning that the number of animals killed on the roads is not accounted for in its totality. Many of them do not die at the time of collision with the car and run into the adjacent vegetation, or are rapidly consumed by scavengers, making accounting difficult (Prada, 2004).

Local surveys about roadkills allow the identification of critical points on the roads, helping in the conservation of animal species. The construction of obstacles which make the drivers slowdown may be indicated for these points of the road. An educative campaign can also be done by putting up signs explaining about the death of animals on the road (Moreira et al., 2006).

Studies are being done in Mato Grosso, Brazil, with the goal of identifying these critical points on the roads of the state (Melo and Santos-Filho, 2007; Souza and Anacleto, 2012), but there is still no research of this nature in indigenous lands. However, some studies have already been conducted in parks, for example, the Iguaçu National Park (Lima and Obara, 2004), on BR-277; the road that goes around Emas National Park (Silveira, 1999); and the road adjacent to the Águas Emendadas Ecologic Station (Rodrigues et al., 2002).

In this context, this study evaluated the impact of roads MT-385 and MT-235 on the fauna of meso- and megavertebrates of the area of Tangará da Serra and the Paresi Indigenous Land (PIL) near the city of Campo Novo dos Parecis. We evaluated the effect of seasonal variations and traffic flow on the number of roadkills on both roads, verifying which species are most affected by the roadkills - considering abundance, biomass, time of activity - and which points have the highest frequency of roadkills.

\section{Material and Methods}

\subsection{Study area}

This study was done on $50 \mathrm{~km}$ of MT-358 road, between the coordinates: $14^{\circ} 37^{\prime} 01.40^{\prime \prime} \mathrm{S}-57^{\circ} 30^{\prime} 16.94$ 'O and $14^{\circ} 31$ '30"S - 57 54'04.73"O, near the cities of Tangará da Serra and Campo Novo dos Parecis (Figure 1); and on $50 \mathrm{~km}$ of MT-235 road, inside the Paresi Indigenous Land, between the coordinates: $13^{\circ} 38^{\prime} 57.14^{\prime \prime S}-57^{\circ} 53$ ' $15.76^{\prime \prime O}$ and $13^{\circ} 33^{\prime} 33.90^{\prime \prime S}-58^{\circ} 24^{\prime} 26.02^{\prime \prime} \mathrm{O}$, near the cities of Campo Novo dos Parecis and Sapezar (Figure 1).

The $50 \mathrm{~km}$ of MT-385 road is outside protected areas and is bordered by cultivation (pastures, sugar cane, cotton, and soy plantations) and a few houses, with small fragments of native vegetation (cerrado and forest). The area around MT-235, on the other hand, is composed of native vegetation (cerrado and cerradão) and, on the stretches where the roads cross rivers, of gallery forests. The entire stretch of road analyzed on MT-235 is inside the Paresi Indigenous Land and was paved in 2009.

The studied areas have a tropical climate, predominantly dry with short wet seasons. Temperatures average between $24.4{ }^{\circ} \mathrm{C}$ and $26.1{ }^{\circ} \mathrm{C}$ with average rainfall of around 1.260 to $1.815 \mathrm{~mm} /$ year (Dallacort et al., 2010).

\subsection{Data collection}

The study was done weekly, always during the morning to avoid further automotive damage to the animal that had been hit making it difficult to identify, or complete consumption for scavengers. During August/2010 and July/2011, we surveyed $2,350 \mathrm{~km}$ in 47 trips on area 1 , and $2.600 \mathrm{~km}$ in 52 trips on area 2, including dry and rainy seasons. We traveled with a vehicle at an average speed of $40 \mathrm{~km} / \mathrm{h}$ (Melo and Santos-Filho, 2007; Souza, 2008).

The distances were measured on the trip odometer (Melo and Santos-Filho, 2007). The first area which was sampled was MT-358, beginning at the intersection at the boundary of the city of Tangará da Serra and continueing $50 \mathrm{~km}$ toward Campo Novo dos Parecis. The second area was road MT-235, starting at the tollbooth in the entrance of the Paresi Indigenous Land (PIL) and continuing $50 \mathrm{~km}$ to the PILboundary (Figure 1).

The geographical coordinates of each point where dead animals were found were recorded using GPS. Animals found on the roadside were considered to have been hit at that same spot.

Animals which could not be identified on the spot were taken to a laboratory for further observations. The specimens which were not collected were taken off the road to avoid recounting. Only the animals on the road or on the roadside were included. 


\subsection{Traffic flow}

Qualitative and quantitative data according to the size of the vehicles were recorded for the analyses of the traffic flow (Souza, 2008) (Figure 2). This survey was done in 4-hour shifts of observation. We started the first day from 0 to 4 hours and finalized on the sixth day, from 20 to 0 hours, totaling 24 hours of observation on alternate days throughout the week. This procedure was repeated to amount to a total of 48 hours of observation during the dry season (August and September, 2010) and the wet season (January and February, 2011). The indigenous people living in the PIL control all the vehicles that go through their land, so they helped with the information about the traffic flow of road MT-235.

\subsection{Statistical analyses}

We used an adhesion test of chi-square to verify the difference in the traffic flow for the different vehicle categories. The same test was used for comparing the rate of roadkills in animals with different times of activity (daytime, nocturnal and crepuscular).

\section{Results}

During the study we registered 178 specimens of roadkills, with $4950 \mathrm{~km}$ traveled in 12 months. This resulted in a rate of 0.035 animals $/ \mathrm{km}$, with different roadkills patterns on each road. On MT-385 the distribution was heterogeneous, with hotspots on kilometers: three (intersection with the city), nine and 41. On MT-235 this pattern was homogeneous,
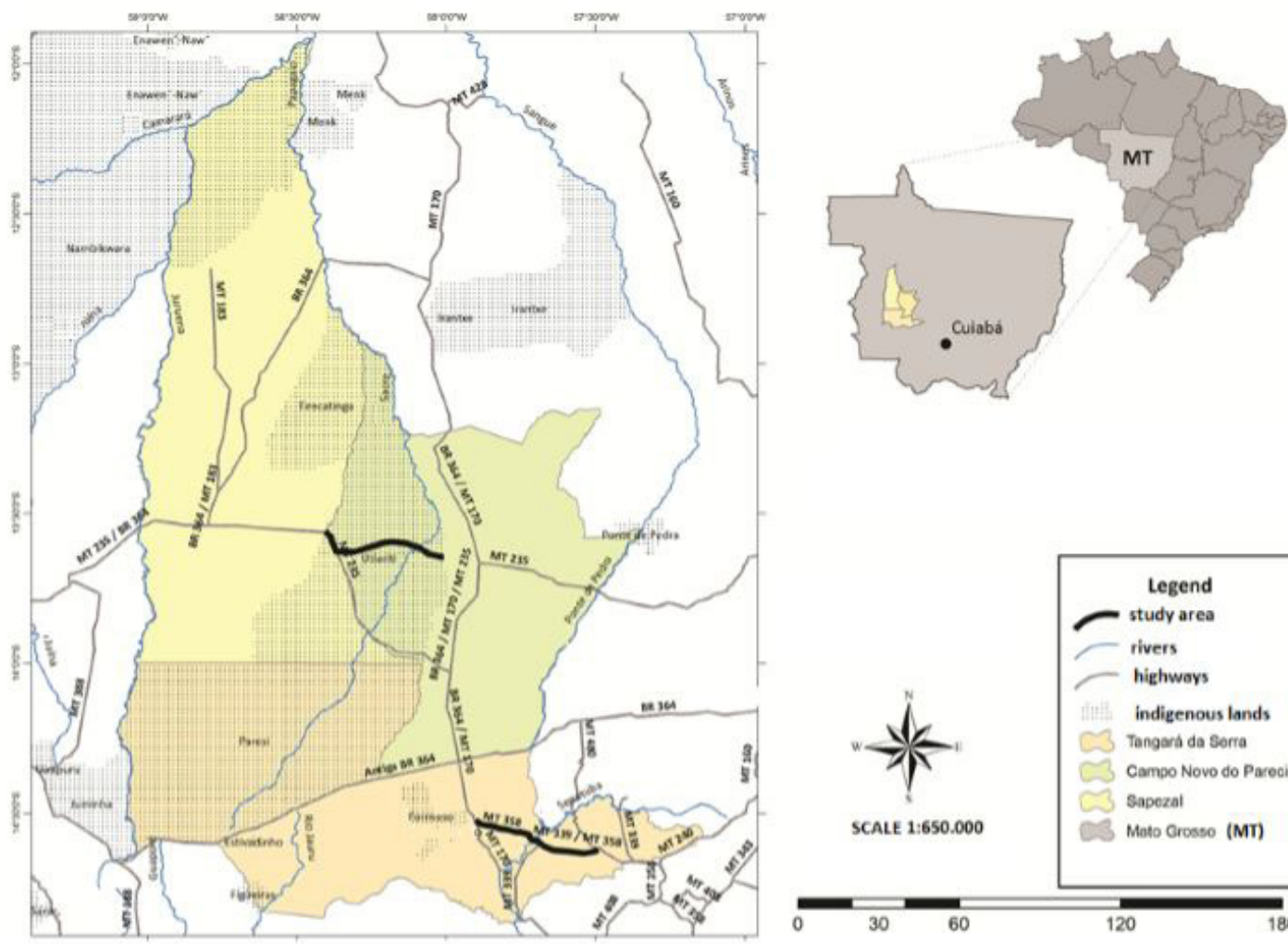

Figure 1. Location of study areas for MT-358 road and MT-235 road (Paresi Indigenous Land)

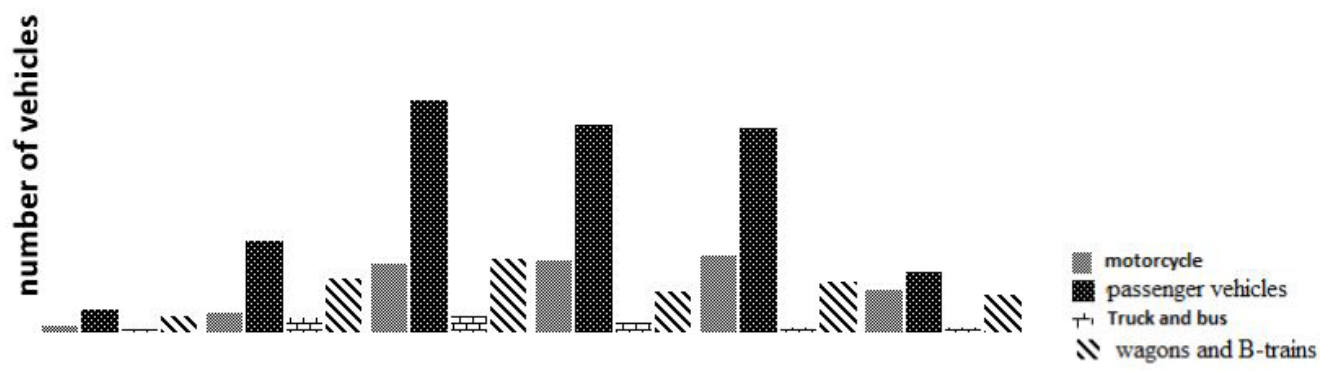

Figure 2. Traffic volume on MT-358 road, separated from 4:00 to 4:00 hours and by vehicle category. 
with one hotspot on kilometer 44. On MT-358, the spots with highest number of roadkills were located in areas of pasture and forest, 87 and 53, respectively. On MT-235 there were more roadkills in the cerrado, 19 in total.

The average number of roadkills on MT-358 was 13 animals/month, and the months with highest rates were June, July and September (dry season) and October and November (wet season). For road MT-235, the average number was two animals/month, with a maximum of eight during the dry season. The months with the highest number of roadkills on MT-358 were October, with 31, and September, with 27.

Considering the whole study, mammals were the most affected, with 135 roadkills (75.8 percent), followed by reptiles, with 11 (6.2 percent), then amphibians, with 10 (5.6 percent), and birds, with nine (5.1 percent). Only 13 (7.3 percent) could not be identified due to advanced state of putrefaction. In total, 33 species, divided into 15 orders, were identified. Among the mammals, 51.1 percent were carnivores, and the most affected species were the crab-eating fox (Cerdocyon thous, $\mathrm{n}=42$ ), the ring-tailed coati (Nasua nasua, $\mathrm{n}=8$ ), and the hoary fox (Lycalopex vetulus, $\mathrm{n}=6)$, (Table 1$)$. Reptiles were the second most affected group, and of these the Bolivian tree snake (Sibynomorphus turgidus, $\mathrm{n}=5$ ) was the most affected, followed by the gold tegu (Tupinambis $\mathrm{sp}, \mathrm{n}=2$ ) (Table 1).

155 roadkills $(0,066$ animals $/ \mathrm{km}$-traveled) were recordeded on MT-358. The most frequent were $C$. thous (23.9 percent, $\mathrm{n}=37)$, E. sexcinctus $(13.5$ percent, $\mathrm{n}=21)$ and T. tetradactyla $(0.7$ percent, $\mathrm{n}=9)$. For road MT-235 (PIL), there were 23 roadkills ( 0.009 animals $/ \mathrm{km}$-traveled), and the most common were $M$. tridactyla (26.1 percent, $\mathrm{n}=6), C$. thous $(21.7$ percent, $\mathrm{n}=5)$ and $E$. sexcinctus (13.0 percent, $n=3$ ) (Table 2).

Endangered species present in national and regional lists were recorded. For example, one maned wolf(Chrysocyon brachyurus) and six giant anteaters (Myrmecophaga tridactyla), both classified nationally as vulnerable (Machado et al., 2008), were found killed inside the Paresi Indigenous Land. An ocelot (Leopardus pardalis), also considered vulnerable (Machado et al., 2008), was found on MT-358. Another seven species considered endangered on a few regional lists (RS, PR, SP, MG, RJ, ES) were also found. Among them there were four South American tapirs (Tapirus terrestris) (one at the PIL) which, despite not being on the national endangered species list, is present on six regional lists (Machado et al., 2008), and on the international endangered species list (IUCN, 2013).

The species which presented the highest loss of biomass for the environment were the South American tapir (T. terrestris) $(\sim 1,200 \mathrm{~kg}$ of aggregated biomass) and the capybara (Hydrochoerus hydrochaeris) ( 400 kg of aggregated biomass), despite a small number of roadkills. However, crab-eating foxes (Cerdocyon thous), with much smaller individual biomass, lost $\sim 462 \mathrm{~kg}$ of aggregated biomass due to the high number of individual roadkills (Table 1).

Regarding traffic flow, MT-358 road registered 1,927 vehicles $\mathrm{x}$ day, with differences in car flow in different time intervals $\left(X^{2}=472.6, \mathrm{gl}=5, P<0.001\right)$. The interval with heaviest traffic was from $8 \mathrm{am}$ to $12 \mathrm{pm}$, with 499 vehicles, and the interval with the lowest flow was from $12 \mathrm{am}$ to $4 \mathrm{am}$, with 63 vehicles (Figure 2). MT 235 road registered 1,951 vehicles $\mathrm{x}$ day, including 800 wagons and B-trains, and 600 small passenger vehicles.

Daytime species were the most affected by the roadkills, representing 73 percent of the animals killed. Crepuscular species were the least affected, representing 9 percent of the total of roadkills (X2 $=54.8, \mathrm{gl}=3, \mathrm{P}<0.001)$.

\section{Discussion}

This study compared vertebrate roadkills in two roads located in different landscapes. The landscape of highway MT-358 is mainly composed of pastures; however, the heterogeneous distribution of the roadkills is due to the concentration of a higher rate of roadkills near rivers, streams, and fragments of forest, similar patterns were found by (Bueno et al., 2015). These areas are legally protected, and are the last refuges for the animal community, as described by Brocardo and Candido-Junior (2012) concerning fragments of mixed ombrophilus forests in the state of Paraná, Brazil.

Indeed, Areas of Permanent Preservation (riparian forests) and Legal Reservations (fragments of mesophytic forests) serve as ecological passageways and are used by forest species because most of the area around MT-358 is composed of grain crops, and small areas of sensu stricto cerrado, with low, sparse vegetation. These passageways connect forest areas where there is enough food and shelter for many of these species, especially arboreal and climbing animals which, because they are close to the roads, are more at risk (Moreira et al., 2006).

The homogeneous distribution of the roadkills on MT-235 indicates its good state of preservation, contrary to MT-358, where the refuge points are only fragments. The low rate of roadkills inside the Paresi Indigenous Land may reflect the higher food availability existing there which, consequently, makes the animals cross the highway less. The quality of the habitat and the presence of vegetation along the highway and around it may influence the roadkill rate (Casella et al., 2006; Lima and Obara, 2004). In addition, this highway had subterranean passageways designed to facilitate animal crossings and minimizing roadkills (Abra, 2012), although no studies have been done in the area to evaluate the efficiency of these passageways.

We registered 0.066 vertebrate animals killed for each kilometer traveled along the $50 \mathrm{~km}$ stretch we surveyed on the MT-358 road. This number is higher than the value of 0.017 found for the roads PR-406 and PR-508, on the coast plains of the state of Paraná (Leite et al., 2012), and 0.014 on the GO 060 road, stretch Goiânia-Iporã (Moreira et al., 2006), which have vegetation similar to the one found on highway MT-358. This may indicate that there are a higher number of vertebrates in the Cerrado/Amazon transition area when compared to other areas, such as the 
Table 1. List of roadkilled animals on MT-358 road and MT-235 road, in Mato Grosso.

\begin{tabular}{|c|c|c|c|c|}
\hline Taxon (Order Species) & Common name & ABTotal & Biom & BiomAgr \\
\hline \multicolumn{5}{|l|}{ MAMMALS } \\
\hline \multicolumn{5}{|l|}{ CARNIVORA } \\
\hline Cerdocyon thous (Linnaeus, 1758) & Crab-eating fox & 42 & 11 & 462 \\
\hline Lycalopex vetulus (Lund, 1842) & Hoary fox & 6 & 8 & 48 \\
\hline Galictis vittata (Schreber, 1776) & Greater Grison & 2 & 3 & 12 \\
\hline Nasua nasua (Linnaeus, 1758) & Coatis & 8 & 7 & 56 \\
\hline Felis catus (Linnaeus, 1775) & Cat & 5 & 4 & 20 \\
\hline Eira barbara (Linnaeus, 1758) & Tayra & 1 & 10 & 10 \\
\hline Canis lupus familiaris (Linnaeus, 1758) & Dog & 3 & 12 & 36 \\
\hline Leopardus pardalis (Linnaeus, 1758) & Ocelote & 1 & 15 & 15 \\
\hline Chrysocyon brachyurus (Illiger, 1815) & Maned wolf & 1 & 25 & 25 \\
\hline \multicolumn{5}{|l|}{ PILOSA } \\
\hline Myrmecophaga tridactyla (Linnaeus, 1758) & Giant anteater & 6 & 50 & 300 \\
\hline Tamandua tetradactyla (Linnaeus, 1758) & Lesser anteater & 11 & 7 & 77 \\
\hline \multicolumn{5}{|l|}{ RODENTIA } \\
\hline Dasyprocta azarae (Illiger, 1811) & Azara's agouti & 1 & & \\
\hline Hydrochoerus hydrochaeris (Linnaeus, 1766) & Capybara & 8 & 50 & 400 \\
\hline \multicolumn{5}{|l|}{ PRIMATES } \\
\hline Sapajus cay (Illiger, 1815) & Capuchin monkeys & 4 & 3 & 12 \\
\hline \multicolumn{5}{|l|}{ CINGULATA } \\
\hline Euphractus sexcinctus (Linnaeus, 1758) & Six-banded armadillo & 24 & & \\
\hline Dasypus novemcinctus (Linnaeus, 1758) & Nine-banded armadillo & 4 & 4 & 12 \\
\hline \multicolumn{5}{|l|}{ ARTIODACTYLA } \\
\hline Ozotoceros bezoarticus (Fischer, 1514) & Deer & 1 & 30 & 30 \\
\hline \multicolumn{5}{|l|}{ DIDELPHIMORPHA } \\
\hline Didelphis albiventris (Linnaeus, 1758) & Opossum & 1 & 3 & 3 \\
\hline Marmosa murina (Linnaeus, 1758) & Murine mouse & 1 & 0.1 & 0.1 \\
\hline \multicolumn{5}{|l|}{ PERISSODACTYLA } \\
\hline Tapirus terrestris (Linnaeus, 1758) & Tapir & 4 & 300 & 1,200 \\
\hline \multicolumn{5}{|l|}{ AMPHIBIANS } \\
\hline \multicolumn{5}{|l|}{ ANURA } \\
\hline Rhinella schneider (Linnaeus, 1758) & Cururu toad & 6 & 2 & 12 \\
\hline Leptodactylus podicipinus (Cope, 1862) & Pointedbelly frog & 2 & & \\
\hline \multicolumn{5}{|l|}{ REPTILES } \\
\hline \multicolumn{5}{|l|}{ SQUAMATA } \\
\hline Tropidodryas striaticeps (Cope, 1869) & Snake & 1 & & \\
\hline Sibynomorphus turgidus (Cope, 1868) & Snake & 5 & 8 & 40 \\
\hline Leptodeira annulata annulata (Linnaeus, 1758) & Banded cat-eyed snake & 2 & & \\
\hline $\begin{array}{l}\text { Oxyrhopus trigeminus (Duméril, Bibron \& } \\
\text { Duméril, 1854) }\end{array}$ & $\begin{array}{l}\text { Brazilian False Coral } \\
\text { Snake }\end{array}$ & 1 & 30 & 30 \\
\hline Boa constrictor (Linnaeus, 1758) & Common boa & 1 & 30 & 30 \\
\hline Tupinambis sp. & Lizard & 2 & 5 & 10 \\
\hline Bothrops sp. & Viper & 1 & & \\
\hline \multicolumn{5}{|l|}{ BIRDS } \\
\hline \multicolumn{5}{|l|}{ CUCULIFORME } \\
\hline Crotophaga ani (Linnaeus, 1758) & Smooth-billed ani & 1 & 0.12 & 0.48 \\
\hline GALLIFORMES & & & 3 & 6 \\
\hline Gallus gallus domesticus (Linnaeus, 1758) & Chicken & 2 & & \\
\hline \multicolumn{5}{|l|}{ TINAMIFORMES } \\
\hline Rhynchotus rufescens (Temminck, 1815) & Red-winged tinamou & 1 & 13 & 13 \\
\hline Coragyps atratus (Bechstein, 1766) & Black Vulture & 1 & 1.6 & 1.6 \\
\hline \multicolumn{5}{|l|}{ PASSARIFORMES } \\
\hline Passer domesticus (Linnaeus, 1758) & House sparrow & 1 & 0.12 & 0.12 \\
\hline
\end{tabular}


Table 2. List of most common roadkilled species found on MT-358 road (out TI) and MT-235 road (Paresi Indigenous Land).

\begin{tabular}{cccc}
\hline STUDY AREA & SPECIES & ABUNDANCE & $\begin{array}{c}\text { AGGREGATED } \\
\text { BIOMASS }\end{array}$ \\
\hline \multirow{3}{*}{ MT 358 road } & Cerdocyon thous & 37 & 407 \\
& Euphractus sexcinctus & 21 & 105 \\
& Tamandua tetradactyla & 9 & 63 \\
\hline \multirow{2}{*}{ MT 235 road } & Myrmecophaga tridactyla & 6 & 300 \\
& Cerdocyon thous & 5 & 55 \\
& Euphractus sexcinctus & 3 & 15 \\
\hline
\end{tabular}

Atlantic Forest or the Cerrado, as seen in studies by Van Der Laan (2012) and Santos-Filho et al. (2012), or that the animal communities are restructuring themselves because of deforestation.

Considering only the animals killed on the highway inside the Paresi Indigenous Land, on highway MT-235, the roadkill rate $(0.009$ animal $/ \mathrm{km})$ was lower than other studies done in roads adjacent to protected areas, such as GO-341, which borders Emas National Park (0.045 animal $/ \mathrm{km}$ ) (Silveira, 1999), and the roads DF-128 and DF-345, which border the Águas Emendadas Ecologic Station, where $0.168 \mathrm{animal} / \mathrm{km}$ was recorded (Rodrigues et al., 2002).

The low roadkills rate in the Paresi Indigenous Land may be related to the lower vehicle flow. Despite the absence of this information in other studies, the vehicle flow must be heavier on roads DF-128 and DF-345, which are inside the urban perimeter of Brasília/DF; the same is the case for the highway GO-341, which goes through the city of Mineros/GO. Besides that, the common presence of B-train trucks on highway MT-235 may diminish roadkills, since these vehicles are slower than cars.

Despite the impossibility of a precise analysis due to the higher number of rainy months than dry months, the driest month (August) and the one immediately following the beginning of rains (October) presented the highest rate of roadkills. Seasonality effects on habitat use was studied by (Mamede and Alho, 2006). The scarcity of food during the dry months, especially in fragmented, highly developed areas, may contribute to this increase in roadkills. Furthermore, in dry seasons the occurrence of fires and scarcity of water may increase the movement of animals in the area. The same roadkill pattern was found by Moreira et al. (2006), where the highest number of roadkills happened in July (dry), with a tendency to decrease during rainy months, when resources increase.

Amphibian roadkills were observed exclusively during two months in the beginning of the rainy season (September and October), a period where these animals move due to reproductive migration or juvenile dispersal (Mazerolle, 2004). Santos-Filho et al. (2012), while studying the seasonal variation of vertebrate roadkills on highway 354 in Minas Gerais, also registered amphibian roadkills only during rainy months. These roadkills contributed to a general increase in the number of roadkills, causing one of the highest peaks registered during all the months of data collection.
The number of birds was small, possibly underestimated. As has already been discussed by Melo and Santos-Filho (2007), the size and weight of these animals mean they are easily thrown off of the highway at the time of impact and into the vegetation along the road, making it impossible to record these roadkills using this methodology. In addition to that, small animals such as birds are more easily consumed by scavengers, decreasing the possibility of recording these roadkills. The high number of medium and large-bodied mammals found in this study may have been influenced by the fact that scavengers require more time to consume them.

The most affected species on highway MT-385 were more habitat generalists, such as $C$. thous, E. sexcinctus and T. tetradactyla. Cerdocyon thous and E. sexcinctus: these species are typical in open areas like the cerrado, allowing the use of more anthropized areas (Moreira et al., 2006; Casella et al., 2006; Melo and Santos-Filho 2007; Souza and Anacleto, 2012). Because they are climbing animals, the $T$. tetradactyla probably crosses the MT-358 highway to go from one fragment of forest to another. This species has been generating concern because of the high number of roadkills found in studies of road ecology (Fischer et al., 2004; Cunha et al., 2010; Seijas et al., 2013), suggesting more specific studies are needed (Seijas et al., 2013). The high rate of roadkill in animals like C. thous may be related to their behavior of following paths and feeding on carcasses, which makes them cross roads many times (Prada, 2004).

In this study, daytime and crepuscular animals were the most affected, since those are the times where traffic is heavier and cars go faster. The traffic flow, the excessive use of the land, and the lack of highway planning may be the main factors contributing to the increase in the number of roadkills, as had been demonstrated by Fischer et al. (2004) in areas close to the Pantanal.

Among the vertebrates, mammals were the most affected in this study. These results are similar to those found by Melo and Santos-Filho (2007) in roads in areas of cerrado (BR-070), in Cáceres-MT. Among these mammals, three endangered species were found, the maned Wolf, the ocelot, and the giant anteater (IUCN, 2013); the same species were found by Souza and Anacleto (2012). Carnivores like the ocelot and the maned wolf are predators with extensive home ranges, c.a. $50 \mathrm{~km}^{2}$ (Dietz, 1984), 
and this factor may contribute to the roadkills, because their area includes the roads.

Similarly, South American tapirs have extensive home ranges, and may occupy forest areas or open areas, traveling for long distances in search of fruits. They are very vulnerable to roadkills. Indeed, South American tapirs represented a large contribution to animal biomass loss due to roadkill (1,200 kg of aggregated biomass), as well as capybaras (400 kg of aggregated biomass), and giant anteaters (300 kg of aggregated biomass). Despite being the smallest animal among those which had the biggest biomass loss, the crab-eating fox, with $\sim 462 \mathrm{~kg}$ of aggregated biomass, indicates the high number of dead individuals. Animals killed on the highway cease to be part of the biomass of animal protein available for other predators and even for humans. Because it is an indigenous land, animals killed on highway MT-235 may become a social problem, since subsistence hunting is still practiced by the Paresi indigenous people.

\section{Conclusion}

The higher number of roadkills on MT-358 may be because of the high fragmentation of the area, with hotspots near Permanent Preservation Areas (rivers and streams). Highway MT-235, inside the Paresi Indigenous Land, had the area around it preserved during its construction, with planning of passageways for the local fauna in the more critical spots, and signs put up - so the rate of roadkill is low on this road. Medium and large-bodied mammals, with daytime/crepuscular habits - times of heavier traffic - were the most affected, although avifauna and small herpetofauna cannot be identified properly due to the faster action of scavengers and the fact that, because of their size, carcasses are more immediately impacted by collision. We emphasize the need of investments aimed to diminish the impact caused by roads, like the building of passageways for local fauna, cleaning tunnels, building fences, and putting up signs. These measures are of fundamental importance for the conservations of vertebrate species.

\section{References}

ABRA, F.D., 2012. Monitoramento e avaliação das passagens inferiores de fauna presentes na rodovia SP 225 no municipio de Brotas, São Paulo. São Paulo: Departamento de Ecologia, Instituto de Biociências, Universidade de São Paulo. 72 p. Master's Thesis.

BAGER, A., 2006. Avaliação dos impactos das rodovias federais a fauna selvagem no extremo sul do Rio Grande do sul-Brasil. Pelotas: Universidade Católica de Pelotas. 73 p.

BISSONETTE, J.A., 2002. Scaling roads and wildlife: the cinderella principle. vol. 48, suppl, pp. 208-214.

BRANDT, A.P., LAMBERTS, A.V.D.H., TRIGO, T.C., HASENACK, H. and FREITAS, T.R., 2001. Mamíferos atropelados na rodovia BR 290, entre Porto Alegre e Cachoeira do Sul, RS: associação espécie e hábitat. In: Resumo do V Congresso de Ecologia do Brasil, 2001, Porto Alegre, RS. Porto Alegre: Centro de Ecologia, UFRGS.
BROCARDO, C.R. and CANDIDO-JUNIOR, J.F., 2012. Persistência de mamíferos de médio e grande porte em fragmentos de floresta ombrófila mista no estado do Paraná, Brasil. Revista Árvore, vol. 36, no. 2, pp. 301-310. http://dx.doi.org/10.1590/ S0100-67622012000200011.

BUENO, C., SOUSA, C.O.M. and FREITAS, S.R., 2015. Habitat or matrix: which is more relevant to predict road-kill of vertebrates? Brazilian Journal of Biology = Revista Brasileira de Biologia, vol. 75, no. 4, suppl. 1, pp. S228-238. PMid:26628243. http:// dx.doi.org/10.1590/1519-6984.12614.

CACERES, N.C., CASELLA, J. and SANTOS GOULART, C., 2012. Variação espacial e sazonal atropelamentos de mamíferos no bioma cerrado, rodovia BR 262, Sudoeste do Brasil. Mastozoología Neotropical, vol. 19, no. 1, pp. 21-33.

CASELLA, J., CÁCERES, N.C., GOULART, C.S. and PARANHOSFILHO, A.C., 2006. Uso de sensoriamento remoto e análise espacial na interpretação de atropelamentos de fauna entre Campo Grande e Aquidauana, MS. In: Anais $1^{\circ}$ Simpósio de Geotecnologias no Pantanal. Campo Grande: Embrapa Informática Agropecuária/ INPE, pp. 321-326.

CASTRO, E.J., 2007 [viewed 28 April 2011] Biodiversidade e problemas ambientais [online]. Rio de Janeiro: Departamento de Geografia, UFRJ. Available from: http://www.geoheco.igeo. ufrj.br/CD_IALE BR/Trabalhos/Castro_Jr_Apresentacao.pdf

CHEREN, J.J., KAMMERS, M. and GHIZONI JÚNIOR, I.R., MARTINS, A., 2007. Mamíferos de médio e grande porte atropelados em rodovias do Estado de Santa Catarina, sul do Brasil. Revista Biotemas, vol. 20, no. 3, pp. 207-231.

CUNHA, H.F., MOREIRA, F.G.A. and SILVA, S.S.D., 2010. Roadkill of wild vertebrates along the GO-060 road between Goiânia and Iporá, Goiás State, Brazil. Acta Scientiarum. Biological Sciences, vol. 32, no. 3, pp. 257-263. http://dx.doi.org/10.4025/ actascibiolsci.v32i3.4752.

DALLACORT, R., MARTINS, J.A., INOUE, M.H., FREITAS, P.S.L. and KRAUSE, W., 2010. Aptidão agroclimática do pinhão manso na região de Tangará da Serra, MT. Revista Ciência Agronômica, vol. 41, no. 3, pp. 373-379. http://dx.doi.org/10.1590/ S1806-66902010000300008.

DIETZ, J.M., 1984. Ecology and social organization of the Maned Wolf (Chrysocyon brachyurus). Smithsonian Contributions to Zoology, no. 392, pp. 1-51. http://dx.doi.org/10.5479/si.00810282.392.

FISCHER, W.A., RAMOS NETO, M.B., SILVEIRA, L. and JACOMO, A.T., 2004. Human transportation networks as ecological barriers for wildlife of Brazilian Pantanal-Cerrado corridors. In: C.L. IRWIN, P. GARRETT, K.P. MCDERMOTT, eds. Proceedings of the 2005 International Conference on Ecology and Transportation, Center for Transportation and the Environment. Raleigh: Center for Transportation and the Environment, North Carolina State University, pp.182-194.

FORMAN, R.T.T., BISSONETTE, D.S.J.A., CUTSHALL, A.P.C.C.D., FAHRIG, V.H.D.L., GOLDMAN, R.F.C.R., JONES, K.H.J.A., TURRENTINE, F.J.S.T. and WINTER, T.C., 2002. Road ecology: science and solutions. Washington: Island Press. 481 p.

FORMAN, T.T.R, ALEXANDRE, L.E., 1998. Roads and their major ecological effects. Annual Review of Ecology and Systematics, vol. 29, no. 1, pp. 207-231. http://dx.doi.org/10.1146/annurev. ecolsys.29.1.207.

FORMAN, T.T.R. and DEBLINGER, R.D., 2000. The ecological road-effect zone of a Massachusetts (USA) suburban highway. 
Conservation Biology, vol. 14, no. 1, pp. 36-46. http://dx.doi. org/10.1046/j.1523-1739.2000.99088.x.

INTERNATIONAL UNION FOR CONSERVATION OF NATURE - IUCN, 2013 [viewed 27 March 2014]. World Conservation International [online]. Red List of Threatened Species. Available from: http://www.iucnredlist.org

LEITE, R.M.S., BÓÇON, R., BELÃO, M. and SILVA, J.C., 2012. Atropelamentos de mamíferos silvestres de médio e grande porte nas Rodovias PR-407 e PR-508, Planície Costeira do Estado do Paraná, Brasil. In: A. BAGER, ed. Ecologia das Estradas: tendências e pesquisa. Lavras: Editora da UFLA, pp. 193-206.

LIMA, S.F. and OBARA, A.T., 2004 [viewed 26 April 2012]. Levantamento de animais silvestres atropelados na Br-277 às margens do Parque Nacional do Iguaçu: subsídio ao programa multidisciplinar de proteção à fauna [online]. Available from: http://faunativa.com.br

MACHADO, A.B.M., DRUMMOND, G.M. and PAGLIA, A.P., 2008. Livro vermelho da fauna brasileira ameaçada de extinção. Brasília: Ministério do Meio Ambiente.

MAMEDE, S.B. and ALHO, C.J.R., 2006. Response of wild mammals to seasonal shrinking-and-expansion of habitats due to flooding regime of the Pantanal, Brazil. Brazilian Journal of Biology = Revista Brasileira de Biologia, vol. 66, no. 4, pp. 991-998. PMid:17299935. http://dx.doi.org/10.1590/S151969842006000600006 .

MAZEROLLE, M.J., 2004. Amphibian road mortality in response to nightly variations in traffic intensity. Herpetologica, vol. 60, no. 1, pp. 45-53. http://dx.doi.org/10.1655/02-109.

MELO, E.S. and SANTOS-FILHO, M., 2007. Efeitos da BR-070 na província Serrana de Cáceres, Mato Grosso, sobre a comunidade de vertebrados silvestres. Revista Brasileira de Zoociências, vol. 9, no. 2, pp. 185-192.

MOREIRA, F.G.A., SILVA, S.S. and CUNHA, H.F., 2006. Impacto do Atropelamento de Animais Silvestres na Rodovia Go 060, Trecho Goiânia - Iporá. In: Anais do II Congresso de Pesquisa, Ensino e Extensão da UFG - CONPEEX; XIII Seminário de Iniciação Cientifica Goiânia, 2005, Goiânia. Goiânia: UFG, pp. 1-3. CD-ROM.
PRADA, C.S., 2004. Atropelamento de vertebrados silvestres em uma região fragmentada do norte do Estado de São Paulo: quantificação do impacto e analise de fatores envolvidos. São Carlos: Universidade Federal de São Carlos, 437 p. PhD Thesis.

RODRIGUES, F.H.G., HASS, A. and REZENDE, L.M., 2002. Impactos de rodovias sobre a fauna de Estação Ecológica de Àgua Emendadas, DF. In: Anais do III Congresso Brasileiro de Unidades de Conservação, 2002, Fortaleza. Fortaleza: CBUC, pp. 585-593.

ROSA, C.A., HOBUS, Q., BAGER, A., 2009. Uso e ocorrência de lontra longicaudis em ambientes influenciados pela rodovia BR-392, no extremo sul do Brasil. In: Anais do IX Congresso de Ecologia do Brasil. São Lourenço: Instituto de Biociências, Universidade de São Paulo.

SANTOS-FILHO, M., PERES, C.A., SILVA, D.J. and SANAIOTTI, T.M., 2012. Habitat patch and matrix effects on small-mammal persistence in Amazonian forest fragments. Biodiversity and Conservation, vol. 21, no. 4, pp. 1127-1147. http://dx.doi. org/10.1007/s10531-012-0248-8

SEIJAS, A.E., ARAUJO-QUINTERO, A. and VELÁSQUEZ, N., 2013. Mortalidad de vertebrados en la carretera GuanareGuanarito, estado Portuguesa, Venezuela. Revista de Biología Tropical, vol. 61, no. 4, pp. 1619-1636. PMid:24432523. http:// dx.doi.org/10.15517/rbt.v61i4.12803.

SILVEIRA, L., 1999. Ecologia e conservação dos mamíferos carnivoros do Parque das Emas. Goiânia: Departamento de Biologia Geral, Universidade Federal de Goiás, 125 p. Master's Thesis.

SOUZA, J. L., 2008. Levantamento de Mamíferos Atropelados na BR-158, Mato Grosso. Nova Xavantina: Universidade do Estado de Mato Grosso, 56 p. Monograph.

SOUZA, J.L. and ANACLETO, T.C.S., 2012. Levantamento de Mamíferos Atropelados na BR-158, Estado do Mato Grosso, Brasil. In: A. BAGER, eds. Ecologia das Estradas: tendências e pesquisa. Lavras: Editora da UFLA, pp. 207-221.

VAN DER LAAN, H.W., 2012. Estrutura de comunidades de mamíferos de médio e grande porte em fragmentos florestais da Amazônia Meridional. Cáceres: Universidade do Estado de Mato Grosso, 98 p. Master's Thesis. 